\title{
La espectrofotometría UV-VIS aplicada al estudio del color y estabilidad en morteros coloreados
}

\author{
The UV-VIS spectrophotometry applied to colour and stability \\ study in coloured mortars
}

Fco.JAVIER ALEJANDRESÁNCHEZ, Dr. Ciencias Químicas
Prof. Asociado de Materiales de Construcción II y Eayos, E. U.

Fecha de recepción: 14-VII-98

Fecha de aceptación: $15-$ XII-98

ESPAÑA

\section{RESUMEN}

Dentro de las metodologías existentes para el estudio del color, se ha realizado una investigación del mismo en morteros coloreados por medio de la espectrofotometría UV-VIS, técnica instrumental que es adaptable al trabajo con materiales sólidos, y que ha sido aplicada anteriormente en el estudio de diversos materiales de construcción. Los resultados obtenidos muestran cómo la citada técnica permite además de evaluar cualitativamente y cuantitativamente los colores de forma sencilla y objetiva, el disponer de las ventajas que conlleva actualmente el análisis instrumental: registro digital del color, tratamiento informatizado de datos y aumento de precisión y exactitud en las comparaciones cromáticas.

\section{SUMMARY}

In the field of methodologies for colour studying, a research of it has been done on coloured mortars by applying uv-vis spectrophotometry, instrumental technique which can be used for solid materials works, and previously applied to building materials study. Results obtained show that the mentioned technique permits to evaluate quantitatively and qualitatively colours in an easy and objective way, besides nowadays advantages of the instrumental analysis: digital colour register, computerised data processing, and precision and exactness increment in chromatic comparisons.

\section{EL COLOR: ASPECTOS TEÓRICOS}

Según el Comité de Colorimetría de la "Optical Society of America", la definición de color adoptada internacionalmente dice: "el color consiste en las características de la luz distinta de sus inhomogeneidades espaciales y temporales", siendo la luz "el espectro de la energía radiante que el observador humano es capaz de percibir por la estimulación que produce en sus retina".

\section{THE COLOUR: THEORETICAL ASPECTS}

According to Colourimetry Committee of the "Optical Society of America", the colour definition adopted internationally is: "colour consists in the characteristics of light different from its space and temporary inhomogeneities", being the light "the spectrum of radiant energy that human observer is able of perceiving by the stimulation it produces in his retina". 
Cuando se observan objetos, la percepción visual resulta un ente psicológico complicado que depende tanto de la composición espectral de la luz (Tabla 1) con que se iluminan los objetos, como de la reflexión que producen de la misma según sea su naturaleza.
When objects are observed, visual perception is a complex psychological entity which depends on spectral composition of the light illuminating them (Table 1), besides the reflection of light they produced according to their nature.

TABLA I (TABLE I)

Espectro de radiación visible por el ojo humano (Visible radiation spectre by human eye)

\begin{tabular}{|c|c|c|c|c|c|c||}
\hline $\begin{array}{c}\text { LONGITUD DE ONDA } \\
\text { WAVE LENGTH } \\
(n m)\end{array}$ & $400-450$ & $450-500$ & $500-570$ & $570-590$ & $590-610$ & $610-750$ \\
\hline COLOR & $\begin{array}{c}\text { VIOLETA } \\
\text { COLOLET }\end{array}$ & $\begin{array}{c}\text { AZUL } \\
\text { BLUE }\end{array}$ & $\begin{array}{c}\text { VERDE } \\
\text { GREEN }\end{array}$ & $\begin{array}{c}\text { AMARILLO } \\
\text { YELLOW }\end{array}$ & $\begin{array}{c}\text { NARANJA } \\
\text { ORANGE }\end{array}$ & $\begin{array}{c}\text { ROJO } \\
\text { RED }\end{array}$ \\
\hline
\end{tabular}

Entre los atributos de esta percepción cabe señalar los siguientes: claridad, tono, saturación, tamaño, forma, localización, textura, pulimento, transparencia, duración, etc. Excepto los tres primeros, todos los demás se refieren a aspectos espaciales y temporales de la percepción compleja. En cambio, la claridad, el tono y la saturación, son los atributos de la llamada percepción simple o sensación visual y constituyen los atributos psicológicos del color.

La definición de estos 3 parámetros, que son los utilizados en este trabajo, es la siguiente:

\section{- Claridad}

Se refiere a la cantidad de luz. En el aspecto físico, este atributo del color se puede asociar con la emitancia de la fuente de luz o con la luminancia del objeto que se trate. En el aspecto práctico, el gris es el color de los cuerpos que no presentan otro atributo que la claridad, y fácilmente se puede imaginar que es posible hacer una escala de colores grises que tendrá, como límites, el blanco y el negro.

\section{. Tono}

Es el atributo por el cual podemos decir que se trata de un color rojo, verde, azul, etc. y, en el aspecto físico, lo relacionamos con la longitud de onda de una luz del espectro continuo (longitud de onda dominante) (Tabla 1).

\section{- Saturación}

Es el atributo que nos indica la relación existente entre el blanco y el color espectral puro, y es inversa a la
Between this perception attributes, it is important to mention the following: brightness, tone, saturation, shape, location, texture, polish, transparency, etc. Except the three first, all the rest are referred to space and temporary aspects of complex perception. In change, brightness, tone, and saturation, are attributes of the simple perception or visual sense, constituting the psychological attributes of colour.

The definition of these three parameters used in this research it is the following.

\section{- Brightness}

It is related to quantity of light. In the physical aspect, this colour attribute can be associated with the light source emitance. In the practical aspect, grey is the colour of objects without any attribute besides brightness, and it can be easily imagined the possibility of making a grey colour scale limited by the white and the black.

\section{- Tone}

It is the attribute which permits to distinguish between red, green, blue, etc., and in the physical aspect it is related with the wave length of continuous spectre (dominant wave length) (Table 1).

\section{- Saturation}

Is the attribute which shows the relation between white and pure spectral colour, and it is inverse to 
proporción de blanco. Si se mezclase un pintura del color gris con otra de color rojo espectral puro, en distintas proporciones, obtendremos una serie de colores que se diferencian en la saturación, y que van desde el gris puro al rojo puro.

\section{COLORIMETRÍA}

La colorimetría es la parte de la ciencia que tiene por objeto la evaluación de la energía radiante en cuanto a su capacidad de producir sensación de color.

El problema práctico al que se enfrenta esta parte de la óptica es el de especificar los colores, es decir, que dado un color, se le pueda asignar una denominación inequívoca que dé las bases para reproducirlo con exactitud, o bien que dada una fuente de luz (primaria, transmitida o reflejada por un cuerpo), se disponga de los métodos científicos para determinar su color una vez establecida la norma de especificación. No se debe olvidar que la forma vulgar de especificar los colores, asignándole a cada uno una palabra o grupo de palabras como amarillo, gris verdoso, rosa pálido, etc., es insuficiente, además de anticientífico por carecer de exactitud.

El citado problema se atacó por el método de las mezclas. El principio básico de este método radica en que con la mezcla aditiva en distintas proporciones de tres luces espectrales puras bien elegidas, se pueden obtener casi todos los colores naturales ${ }^{1}$. Estas luces primarias o colores primarios son el rojo $(\lambda=700 \mathrm{~nm})$, el verde $(\lambda=546,1 \mathrm{~nm})$ y el azul-violeta $(\lambda=453,8 \mathrm{~nm})$, y su mezcla dos a dos entre ellos, da lugar a los colores secundarios (amarillo, magenta y celeste) (Figura 1).

El método de mezclas ha dado lugar al establecimiento de diversos sistemas colorimétricos, entre los que destacamos el Sistema Internacional de Especificación del Color (basado en un sistema RGB). white proportion. If a grey paint were mixed with red spectral pure colour, in different proportions, we would obtain colours differing in saturation, including pure grey and red.

\section{COLOURMETRY}

The colourmetry is the science part aimed at evaluating radiant energy in its capacity of making the colour sense.

This optics part is confronting with the practical problem of colour specifying, that is to say, given a colour, it can be assigned one unequivocal denomination giving the bases to reproduce it exactly, or given a light source (primary, transmitted $o$ reflected by an object), are available the scientific methods to determinate its colour, once is established the specificycation norm. It must not forget that the vulgar form to specify colours, assigning each one a word or a group of words as yellow, grey-green, pale pink, etc., is not enough, besides it is unscientific by its exactness lacking.

The mentioned problem was attacked by the mix method. The basic beginning of this method resides in the additive mix in different proportion of three pure spectral lights that have been well chosen, obtaining in this way almost all the natural colours ${ }^{1}$. These primary lights or primary colours are: $r e d(\lambda=700 \mathrm{~nm})$, green $(\lambda=546,1 \mathrm{~nm})$ and blue $(\lambda=453,8 \mathrm{~nm})$, and their mix made two to two, result in secondary colours (yellow, magenta, sky-blue) (Figure 1).

The mix method has given as result the establishment of several colourmetrics system, between them we emphasise the International System of Colour Specification (based on a RGB system).

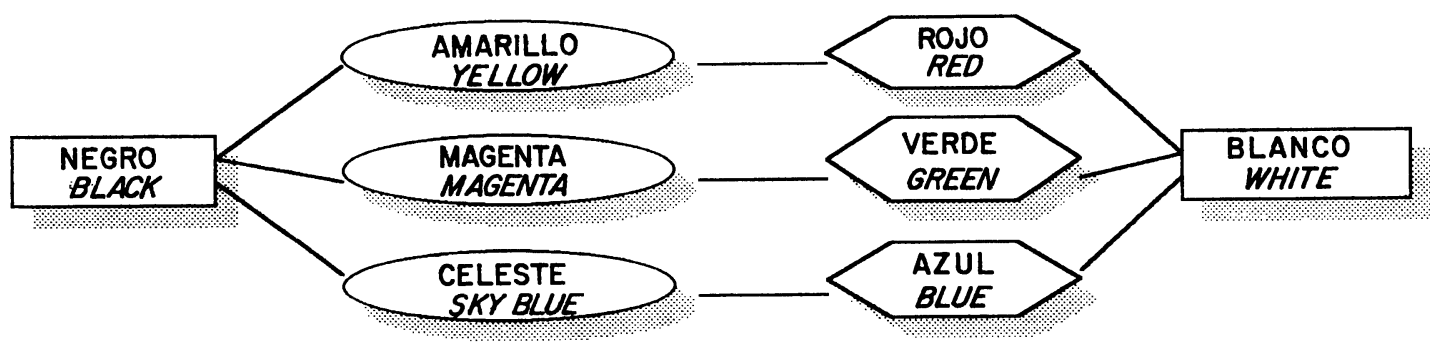

Figura 1.- Colores primarios y secundarios.

Figure 1.- Primary and secondary colours.

${ }^{1}$ Las leyes experimentales de las mezclas fueron elaboradas por Grassmann

1 Mixing experimental laws were elaborated by Grassmann in 1853 en 1853 
En construcción, los sistemas colorimétricos de evaluación usados tradicionalmente, se apoyan en catálogos de colores derivados del sólido de color por subdivisión de sus escalas (catálogo de Munsell, cartas de colores como el RAL, escalas cromáticas...), y su fundamento es la comparación de colores por medio de la percepción visual (1).

Esta comparación visual tiene dos inconvenientes básicos: el primero, sería la imposibilidad de hacer un catálogo con todos los colores diferentes que puede distinguir el observador humano normal ${ }^{2}$, y el segundo, es que lleva como factor añadido el subjetivismo, máxime en una disciplina como la del color, donde poca gente reconoce sus limitaciones.

Frente a estas limitaciones, la utilización de la espectrofotometría como técnica de estudio del color, permite la obtención de las curvas espectrales que son una especie de carnet de identidad. El color que presenta un material es el resultado de la combinación de la absorción (o reflexión) de radiación en cada una de las bandas de color del espectro visible (Tabla 1). Así, cualquier material tiene un espectro característico que nos indica la radiación que absorbe o refleja a una determinada longitud de onda de la radiación incidente. Cuando la longitud de onda está comprendida entre 400 $\mathrm{nm}$ y $750 \mathrm{~nm}$ (zona del espectro de radiación visible), se obtiene una curva espectral (2) que es el resultado de la distinta absorción (o reflexión) en cada banda de radiación. Cada curva espectral representa a un color, por lo tanto, aunque puede haber colores representados por varias curvas con distinta composición espectral, no obstante, estos colores aparecen iguales al ojo y se llaman metámeros.

Por último, se puede decir, como introducción al empleo de la espectrofotometría, que lejos de rivalizar con la evaluación visual, la complementaría, añadiendo las importantes ventajas que supone el análisis instrumental: registro digital del color, tratamiento informatizado de datos y aumento de precisión y exactitud en las comparaciones cromáticas.

\section{ESPECTROFOTOMETRÍA UV-VIS}

La obtención de las curvas espectrales se ha realizado mediante un espectrofotómetro de scanning UV-VIS 2101 PC, marca Shimadzu, al que se le ha adaptado una esfera de reflexión difusa que permite el trabajo con muestras de materiales sólidos.

\footnotetext{
2 Se calcula que el hombre puede distinguir unos de otros hasta diez millones de colores.
}

In the building world, the colourmetric systems used traditionally to evaluate, are based on colour catalogues derived from the colour solid by subdivision of its scales (Munsell catalogue, RAL, chromatic scales, etc.), and their foundation is to compare colours using the visual perception (1).

This visual comparison has two disadvantages: firstly, it is the impossibility of doing a catalogue with all different colours which a normal human observer $^{2}$ is available to distinguish, secondly, it is the subjective factor added, especially in a colour subject, where few people noticed their limits.

Against these limits, the spectrophotometry used as a technique for colour studying, permits to obtain spectral curves which are a special "fingerprint". The colour showed by one material is the result of combining the radiation absorbed o reflected in each of the colour bands in the visible spectre (Table 1). So, any material has a characteristic spectre which informs about absorbed o reflected radiation in a fixed wave length of the incident radiation. When length wave is between $400 \mathrm{~nm}$ and $750 \mathrm{~nm}$ (spectre zone of visible radiation), it is obtained a spectral curve (2) which is the result of different absorption (or reflection) in each radiation band. Each spectral curve represents one colour therefore, although it is possible to find colours represented by several curves with different spectral composition, nevertheless, these colours seemed equal to eyes.

\section{Finally, it can be said as introduction of} spectrophotometry employ, that far from competing with visual evaluation, it can be a complementary technique, adding the important advantages of instrumental analysis: digital colour register, computerised data processing and precision and exactness increment in chromatic comparisons.

\section{UV-VIS SPECTROPHOTOMETRY}

Spectral curves procurement has been achieved by means of a UV-VIS scanning spectrophotometer, 2101 PC mark, complemented with a diffused reflection sphere which permits to work with solid samples.

${ }^{2}$ It is calculated that the man can distinguish until ten millions colours. 
Se ha determinado la reflectancia de las probetas de mortero en el modo transmitancia en porcentaje, anchura de rendija de $5 \mathrm{~mm}^{2}$, intervalo de muestreo de $0,5 \mathrm{~nm}$ y con un rango de registro de $400 \mathrm{~nm}$ a $750 \mathrm{~nm}$ (que corresponde al espectro visible). El blanco recomendado y utilizado para el calibrado interno del aparato ha sido sulfato de bario $\left(\mathrm{BaSO}_{4}\right)$, con un $99,9 \%$ de pureza.

\section{MUESTRAS Y MORTEROS}

Las medidas de reflectancia se han efectuado sobre tres tipos de muestras:

\section{- En polvo}

Es el caso del humo de sílice (HS), adición puzolánica de color gris, y del $\mathrm{BaSO}_{4}$, blanco recomendado para el calibrado. Estos dos compuestos han sido compactados manualmente en pastillas de $2 \mathrm{~cm}$ de $\emptyset$.

\section{- Catálogo RAL}

Se ha utilizado como referencia universal para establecer la comparación entre colores.

\section{- Morteros}

Los morteros empleados en la investigación han sido morteros de cal y albero ${ }^{3}$ (MCAL) (3), estudiándose la estabilidad de su color con el paso del tiempo y la influencia de la adición de HS sobre el mismo.

Para la confección de las probetas de MCAL empleadas en este ensayo, ha sido necesario hacer un molde prismático de pasta acrílica con unas dimensiones de $45 \times 33 \times 15 \mathrm{~mm}$, que proporcionaba probetas de $37 \times 26 \times 15 \mathrm{~mm}$, que son unas medidas adecuadas para trabajar en el espectrofotómetro UV-VIS 2101 PC.

El proceso de enmoldado se ha basado en el descrito en la Norma UNE 83-821-92/Exp. (apartado 6.2.3.) (4) para las probetas de resistencia a compresión y a flexión, pero adaptado a las dimensiones del nuevo molde, y con una modificación de su base inferior, donde se ha utilizado una fina película de plástico (polietileno). Con esta técnica se ha conseguido que al desmoldar la probeta, la cara que está en contacto con el plástico tenga una textura sin asperezas ni realces ${ }^{4}$,

\footnotetext{
${ }^{3}$ El albero es un árido autóctono, con un color próximo al ocre claro y al amarillo oro y que es debido a la presencia de pequeños porcentajes de óxido de hierro en forma de gohetita.

4 El tipo de textura que presenta un material (lisa, rugosa, con oquedades, etc.) influye en la medida del color por medio de esta técnica, por ello, se eligió un sistema de preparación de probetas que nos ofreciera siempre una misma textura, que fuera lo suficientemente homogénea como para conseguir una buena reproducibilidad en las medidas.
}

It has been determined the mortar test pieces reflectance in transmittance mode expressed in percentage, using: $5 \mathrm{~mm}^{2}$ slit width, $0.5 \mathrm{~nm}$ sampling interval and detection range between $400 \mathrm{~nm}$ and $750 \mathrm{~nm}$ (visible spectre). The recommended white, used as standard, was barium sulphate $\left(\mathrm{BaSO}_{4}\right)$, having $99.9 \%$ purity.

\section{SAMPLES AND MORTARS}

Reflectance measures have been made on three different samples:

\section{. In powder}

This is the silica fume case, pozzolanic addition of grey colour, and $\mathrm{BaSO}_{4}$, white substance recommended as standard. These two compounds have been compacted manually in $2 \mathrm{~cm} \Phi$ pills.

\section{- RAL catalogue}

It has been used as universal reference to establish the comparison between colours.

\section{- Mortars}

Mortars used in the research have been lime and albero mortars ${ }^{3}$ (MCAL) (3), studying the stability of their colours against time, and the influence of silica fume on their colours.

To make MCAL mortar test pieces used in this experiment, it has been necessary to make a prismatic acrylic paste mould sized $45 \times 33 \times 15 \mathrm{~mm}$, which permits to obtain $37 \times 26 \times 15 \mathrm{~mm}$ mortar test pieces. These measures are suitable to work in the UV-VIS 2101 PC spectrophotometer.

The moulding process it is based in one described in Norm UNE 83-821-92/Exp. (paragraph 6.2.3.) (4) for test pieces of compressive and flexural strength, but adapted for the new mould dimensions, and with a change in its inferior base, where it has been used a fine plastic film (polietilene). With this technique, it has been possible during the test piece stripping, that the face contacting with the plastic film had a texture without roughness ${ }^{4}$, due to polietilene even

3 The albero is an autochthonous material with a colour near to pale ochre and gold yellow. This colour is due to low percentages of iron oxides in goethite form.

4 The texture type showed by a material (even, rough, with pores, etc.) has influence on colour measures applying this technique, that is why it was selected a mortars elaboration procedure which always offers the same texture, having the adequaie homogeneity to obtain good reproducibility measures. 
debido a la superficie lisa del polietileno y a la baja adherencia entre el mortero y ella. Esta cara es la que serviría para la determinación de la estabilidad del color.

Las probetas se curaron hasta los 28 días en la cámara, para conseguir una resistencia mínima que nos permitiera su manejo. A partir de esa edad, se expusieron a condiciones ambientales con el fin de evaluar el efecto del agua de lluvia y de la radiación solar sobre su color. Las condiciones de curado de este período se especifican en la tabla 2. surface and to the low adherence between them. This face is used to determinate colour stability.

The test pieces were cured until 28 days in chamber to obtain a minimum strength for operating. Starting from this age, they were exposed to environmental conditions for evaluating rain and sun radiation effect on their colour. Maintenance conditions are specified in the table 2.

TABLA \| (TABLE II)

Condiciones de confección y curado de las probetas de medida de color (Making and curing conditions of colour measurement test pieces)

\begin{tabular}{|c|c|c|c|}
\hline $\begin{array}{l}\text { Condiciones de conservación } \\
\text { Maintenance conditions }\end{array}$ & $\begin{array}{l}T=20 \pm 2{ }^{\circ} \mathrm{C} \\
H R=65 \pm 5 \%\end{array}$ & $\begin{array}{l}T=20 \pm 2{ }^{\circ} \mathrm{C} \\
H R=65 \pm 5 \%\end{array}$ & $\begin{array}{l}T=10^{\circ} \mathrm{C} \text { (min.) }-40^{\circ} \mathrm{C} \text { (max.) } \\
H R=40 \%(\min )-70 \%(\max )\end{array}$ \\
\hline $\begin{array}{l}\text { Tiempo de conservación } \\
\text { Maintenance time } \\
\text { Condiciones de confección } \\
\text { Making conditions }\end{array}$ & $\begin{array}{l}24 \text { horas } \\
24 \text { hours } \\
\text { En el molde } \\
\text { In mould }\end{array}$ & $\begin{array}{c}28 \text { dias } \\
28 \text { days } \\
\text { Desmoldada } \\
\text { Out of the mould }\end{array}$ & $\begin{array}{l}\text { Hasta edad de medida } \\
\text { Until measurement time } \\
\text { Desmoldada } \\
\text { Out of the mould }\end{array}$ \\
\hline
\end{tabular}

Se consideró de interés la introducción un MCAL fabricado con albero parcialmente decolorado ${ }^{5}(5)$ con el objeto de disponer de una probeta con el color albero más claro posible, pero que mantuviera la identidad del mismo. La citada probeta sería una referencia mínima del grado de decoloración aceptable, en el caso de que se produjese una pérdida de color en los MCAL con el paso del tiempo. El caso opuesto de oscurecimiento (pérdida de saturación) del mortero, se cubre con las probetas de MCAL con adición de HS.

\section{RESULTADOS}

Los resultados obtenidos se han agrupado en tres apartados:

(1) Influencia del tono, claridad y saturación en las curvas espectrales de reflectancia

(2) Comparación del color albero con colores del catálogo RAL

(3) Influencia de la adición de HS y del tiempo en el color de los MCAL.

\footnotetext{
${ }^{5}$ La decoloración del albero se hizo mediante la técnica del ditionitocitrato-bicarbonato, basada en el poder reductor del ditionito, capaz de reducir todos los óxidos de hierro III a II, en un pH comprendido entre 7 y 9 (Mehra y Jackson, 1969).
}

It was considered interesting to introduce one $M C A L$ made with albero partially discoloured ${ }^{5}(5)$, the reason was to have a mortar test piece less coloured than the albero, in the brightness aspect, but maintaining its identity. The mentioned mortar test piece could be a minimum reference for discolouring, in case it was produced a discolouring with time evolution. The opposite case, saturation loosing, it is covered with the mortar test pieces with HS addition.

\section{RESULTS}

The results obtained are been grouped in three paragraph:

(1) Brightness, tone and saturation influence on reflectance spectral curves

(2) Comparison between albero colour and RAL catalogue colours

(3) Time and silica fume addition influence on MCAL colour.

5 Albero discolouring was made by the ditionite-citrate-bicarbonate technique, based on the ditionite reduction power, which is able to reduce all iron oxides from III to II, in a pH interval between 7 and 9 (Mehra y Jackson, 1969). 


\section{1) Influencia del tono, claridad y saturación en las curvas espectrales de reflectancia}

\section{- Claridad}

Dos son los gráficos elaborados para este estudio (Figura 2).

\section{Brightness, tone and saturation influence on reflectance spectral curves}

\section{- Brightness}

Two are the graphics elaborated for this study (Figure 2).

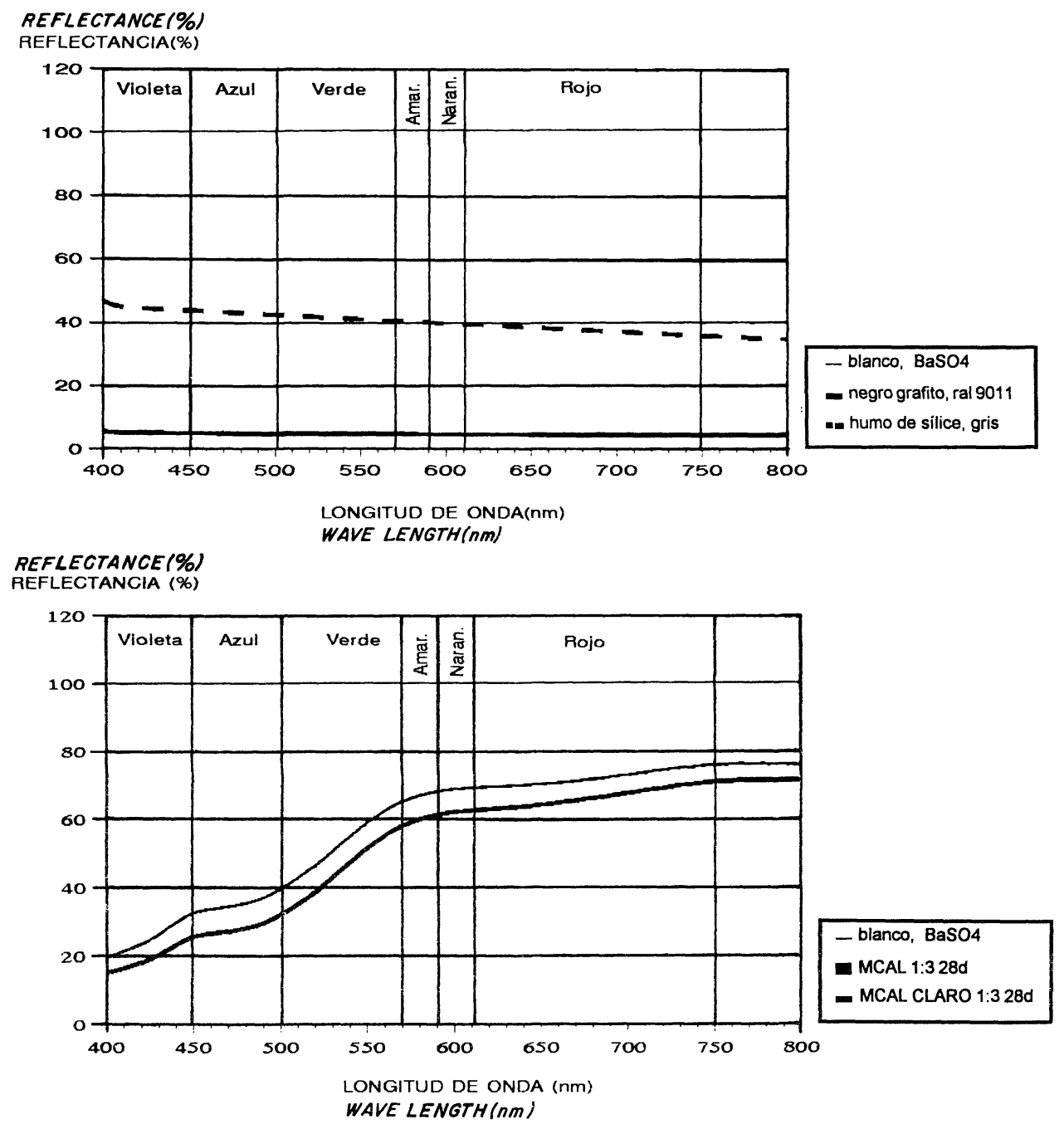

Figura 2.- Reflectancia del negro grafito (RAL 9011), HS, MCAL y MCAL claro.

Figure 2.- Graphite black (RAL 9011), HS, MCAL and pale MCAL reflectance.

En el primero de los gráficos se pueden ver tres líneas espectrales que corresponden a los colores blanco $\left(\mathrm{BaSO}_{4}\right)$, gris del humo de sílice y negro grafito de RAL 9011. Como la claridad se refiere a la cantidad de luz reflejada por un cuerpo, el color blanco, confeccionado con un patrón de $\mathrm{BaSO}_{4}$, aparece como una línea horizontai con el $100 \%$ de reflectancia para todas las longitudes de onda $(\lambda)$. En el lado opuesto, tenemos al color negro grafito, que se muestra como
The first graphic shows three spectral lines that belongs to white $\left(\mathrm{BaSO}_{4}\right)$, silica fume grey and graphite black (RAL 9011). As brightness refers to light quantity reflected by a material, white colour, made of $\mathrm{BaSO}_{4}$ standard, appears as a horizontal line with $100 \%$ reflectance in all wave length $(\lambda)$. The opposite case is graphite black, that 
una línea horizontal con un $5 \%{ }^{6}$ de reflectancia para todas las $\lambda$. Por último tenemos al gris, que es el color de los cuerpos que no presentan otro atributo que la claridad, y que en esta ocasión se encuentra representado por una línea espectral casi horizontal, con una reflectancia del $40 \%$, que corresponde al color del HS. La característica común a los tres es que ninguno de ellos tiene un tono que resalte más que los demás, por lo tanto son acromáticos.

En el segundo gráfico se puede observar la influencia de la claridad en las curvas espectrales de dos MCAL significativos, el mortero base 1:3 y el mortero 1:3 con albero decolorado. El color del primero a los 28 días, tal y como se puede apreciar, es el resultado de la combinación de distintos tonos entre los cuales predominan los rojos $(65 \%)$, naranjas $(60 \%)$, amarillos $(60 \%)$ y verdes $(45 \%)$, el del MCAL claro 1:3 (28 días), tiene la misma proporción relativa entre tonos (curvas paralelas), pero es más claro porque todos ellos tienen unos valores de reflectancia superiores a los del MCAL. En concreto, la reflectancia media ${ }^{7}(\overline{\mathrm{R}})$ del MCAL ha sido $52,14 \%$ y la del MCAL claro ha sido $58,38 \%$, lo que supone una diferencia de $6,24 \%$.

\section{- Tono}

El efecto de este atributo se puede observar en el siguiente gráfico (Figura 3). is showed as a horizontal line with a $5 \%{ }^{6}$ reflectance in all $\lambda$. Finally, we have grey, that is the colour of materials without any attribute except brightness, and it is represented in this occasion by a line almost horizontal with $40 \%$ reflectance that belongs to $H S$ colour. These colours have a characteristic in common, none of them have a tone standing out of the rest, therefore they are achromatic.

In the second graphic it can be observed brightness influence on the spectral curves of two significant MCAL, 1:3 base mortar and 1:3 mortar containing discoloured albero. The first one colour at 28 days, is the result of combining different tones, between them are prevailing reds $(65 \%)$, oranges $(60 \%)$, yellows (60\%) and greens (45\%). Pale MCAL 1:3 (at 28 days), has the same relative proportion between tones (parallel curves), but it is more pale than the other one because all tones have higher reflectance values respect to $M C A L$. To sum up, the average reflectance ${ }^{7}(\bar{R})$ of MCAL has been $52.14 \%$ and for pale MCAL has been $58.38 \%$. This represents a $6.24 \%$ difference.

\section{. Tone}

This attribute effect can be observed in the next graphic (Figure 3).

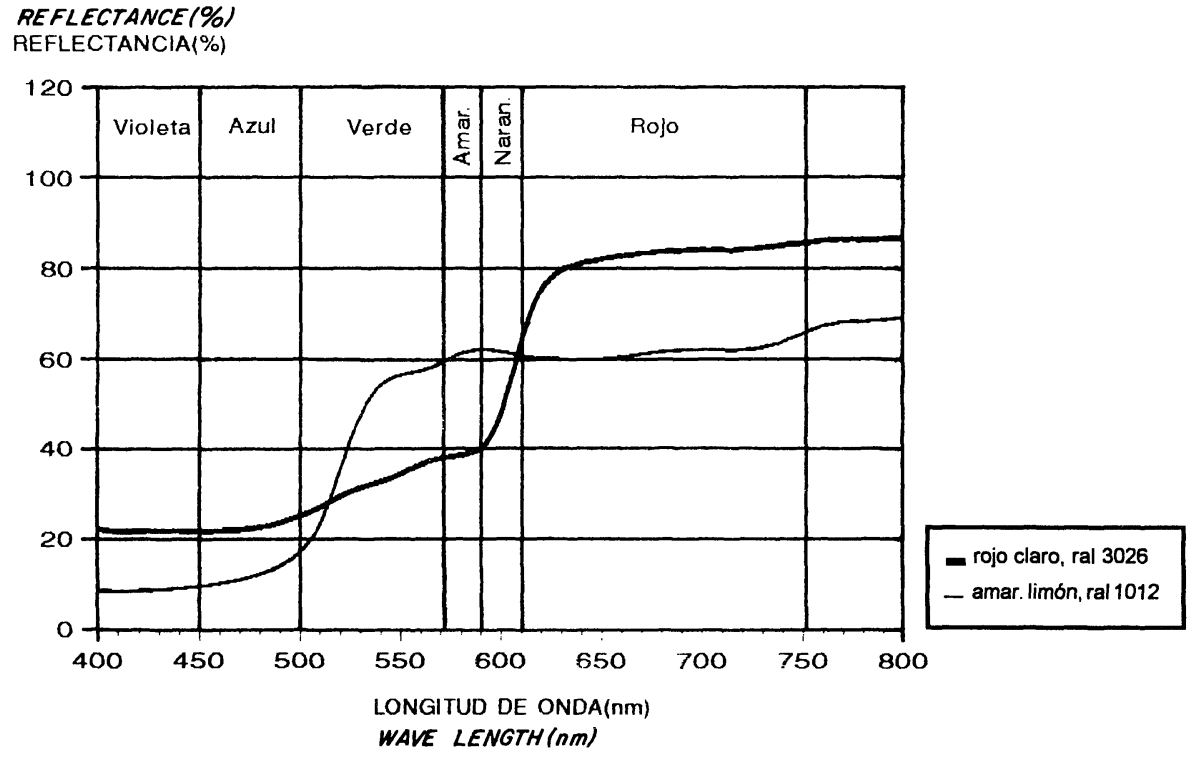

Figura 3.- Reflectancia del rojo claro (RAL 3026) y amarillo limón (RAL 1012).

Figure 3.- Pale red (RAL 3026) and lemon yellow (RAL 1012) reflectance.

\footnotetext{
${ }^{6} \mathrm{Al}$ tratarse de un análisis cualitativo, los porcentajes se han calculado de forma aproximada con un $\pm 2 \%$ de error, ofreciendo, de esta forma, un nivel suficiente de información.

${ }^{7}$ Estos valores son parte de los resultados suministrados por la opción de estadisticas de series del programa de representación gráfica Harvard Graphics, y corresponden a la media de los 800 puntos que forman la curva espectral de cada color.
}

\footnotetext{
${ }^{6}$ Being a qualitative analysis, percentages has been calculated approximately with a $2 \%$ error, offering in this way a sufficient information level.

${ }^{7}$ These values are part of the results provided by the statistics option of the Harvard Graphics program, and correspond to a 800 points average which form the spectral curve of each colour.
} 
Como se puede observar, la curva relativa al color rojo claro de RAL 3026 no corresponde a la de un color espectral puro, que estaría representado exclusivamente por un pico dentro del intervalo de 610 a $750 \mathrm{~nm}$. En cambio, este color tiene un elevado porcentaje de reflectancia ( $85 \%$ ) en todo el intervalo correspondiente los tonos rojos, media en el del naranja y amarillo (50\%), y baja en los tonos verdes $(30 \%)$. Como la combinación de los rojos con verdes dan como resultado el tono amarillo (Figura 1), el color se reduce a la combinación de tonos rojos predominantes, con naranjas y amarillos minoritarios, que dan lugar al rojo claro de RAL 3026.

En el caso del color amarillo limón de RAL 1012, se produce un descenso de la reflectancia en los tonos rojos, que ahora es de un $60 \%$, y un aumento en naranjas y amarillos $(60 \%)$ y verdes $(40 \%)$. Teniendo en cuenta como en el caso anterior, que tonos rojos más verdes dan amarillos, el color amarillo limón ha surgido de la combinación de tonos amarillos y naranjas predominantes, con rojos minoritarios.

\section{- Saturación}

La influencia de este último atributo se observa en el siguiente gráfico (Figure 4).

En este ejemplo se han utilizado las curvas espectrales producidas por el color azul claro de RAL 5012 y el azul gris de RAL 5008.
As it can be observed, the curve relative to pale red colour (RAL 3026) does not correspond to one of a pure spectral colour which could be exclusively represented by a pick in the $610 \mathrm{~nm}-750 \mathrm{~nm}$ intervai. In change, this colour has a high reflectance percentage (85\%) in all red tones interval, medium in the orange and yellow ones (50\%) and low in the green one (30\%). As combining red and green tones it is possible to obtain a yellow tone (Figure 1), the final colour is the result of mixing predominating red tones with oranges and yellow minorities, giving pale red ( $R A L$ 3026).

In the case of lemon yellow colour (RAL 1012), there is a diminution on red tones reflectance, being now $60 \%$, and an oranges and yellows (60\%) and greens (40\%) increase. Bearing in mind that red tones added to greens give yellows, the lemon yellow colour has appeared by combining yellow tones and predominating oranges, with minorities reds.

\section{- Saturation}

The influence of this last attribute it is observed in the next graphic (Figure 4).

In this example it has been used the spectral curves produced by pale blue colour (RAL 5012) and grey blue (RAL 5008).

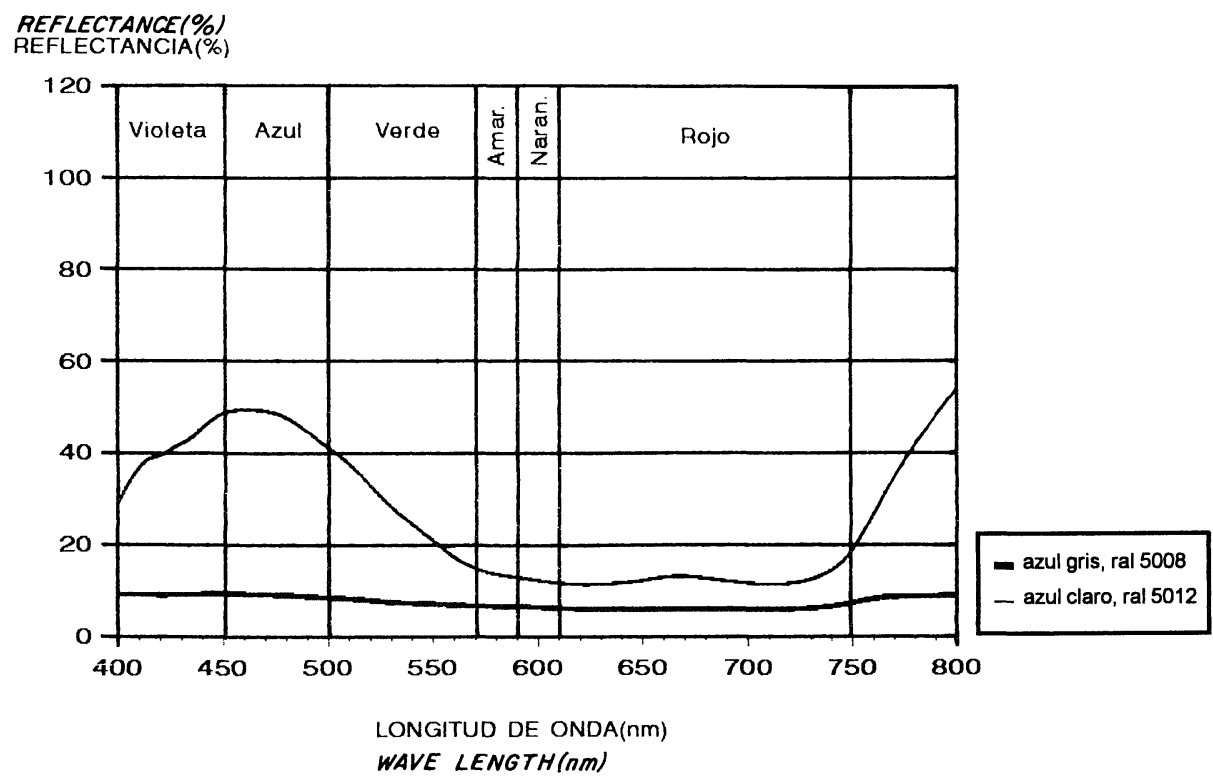

Figura 4.- Reflectancia del azul claro (RAL 5012) y azul gris (RAL 5008).

Figure 4.- Pale blue (RAL 5012) and grey blue (RAL 5088) reflectance. 
Como se ve en el gráfico, el azul claro es el resultado de la combinación de tonos azules con una reflectancia del $45 \%$, violetas con el $40 \%$ y verdes con un $30 \%$. El azul gris, es, en cambio, un color menos saturado respecto del anterior, ya que se ha producido una disminución de la reflectancia en los tonos que lo caracterizan, tendiendo casi a la línea completamente recta y horizontal, que sería un gris. Es decir, la saturación de un color se traduce en la transformación progresiva de una línea recta más o menos horizontal, que corresponde a un gris, en una curva espectral con una banda o pico en uno o varios tonos claramente diferenciados.

En el citado ejemplo, el azul gris tiene asociado también un ligero efecto de oscurecimiento, que ha ocasionado un descenso de la reflectancia en los tonos rojos, naranjas y amarillos. El color no saturado puro y sin oscurecimiento, correspondería a una curva paralela a la del azul gris, pero con un $6 \%$ más de reflectancia en todos los tonos.

\section{2) Comparación del color albero con los colores del catálogo RAL}

Otro de los aspectos de interés de la espectrofotometría lo constituye su aplicación como herramienta para efectuar comparaciones objetivas entre colores. En esta ocasión, se ha comparado el color de los MCAL con referencias de validez internacional (carta de colores RAL). Inicialmente, para reducir el ámbito de trabajo, la comparación fue visual, llegando por eliminación hasta dos colores, el amarillo arena de RAL 1002 y el beige de RAL 1001, que eran los más parecidos. El ensayo de medida de la reflectancia de los tres colores puede verse en la figura 5 .

Como se puede apreciar, los colores amarillo arena y beige, son muy similares entre sí, diferenciándose solamente en que el último tiene mayor reflectancia en los tonos azules y violetas, que lo transforman en un color menos saturado que el amarillo arena.

Respecto a la comparación con el color del MCAL, se puede ver cómo ambos tienen un menor porcentaje (en torno a un $6 \%$ ) de tonos rojos, naranjas y amarillos, lo que hace que ambos sean colores menos saturados que el del MCAL. Esto significa que ambos colores se podrían obtener mediante la mezcla del color del MCAL con un cierto porcentaje de gris.

\footnotetext{
${ }^{8}$ Las reflectancias producidas por este color en el intervalo de longitudes de onda comprendido entre $750 \mathrm{~nm}$ y $800 \mathrm{~nm}$, pertenecen a la zona de infrarrojos, que no son visibles por el ojo humano y que, por tanto, no influyen en la sensación visual.
}

As it is observed in the graphic, pale blue is the result of combining blue tones with $45 \%$ reflectance, violets with $40 \%$ and greens with $30 \%{ }^{8}$. Grey blue, it is in change a less saturated colour respect the previous one, because it has been produced a reflectance decreasing in its characteristic tones, tending almost completely to a straight and horizontal line, that is a grey. That is to say, the saturation of one colour it is translated in the progressive transformation of one straight line, more or less horizontal, that correspond to a grey, in one spectral curve having a band or pick clearly distinguished in one or several tones.

In the mentioned example, grey blue has associated also a light darkness effect, that has generated a reflectance decreasing in reds, oranges and yellows tones. Pure saturated colour without darkness would correspond to a parallel curve to the grey blue one, but with $6 \%$ reflectance added in all tones.

\section{2) Comparison between albero colour and RAL catalogue colours}

Another interesting aspect of spectrophotometry it is constituted by its application as a tool to do objective comparisons between colours. In this case, it has been compared MCAL colour with international standards ( $R A L$ colours catalogue). Initially, for limiting the work field, the first comparison was visual, obtaining two colours by elimination, sand yellow (RAL 1002) and beige (RAL 1001), being the most similar ones. The measurement reflectance essay of the three colours gave the figure 5 .

As it can be evaluated sand yellow and beige colours are very similar, the only difference is that the last one has higher reflectance in blue and violets tones, which transform it in a less saturated colour than sand yellow.

Respect to comparison with MCAL colour, it can be seen that both of them have lower percentage (approximately 6\%) of red, orange and yellow tones, which means that both colours are less saturated than the MCAL one. This also means that both colours could be obtained by mixing MCAL colour with certain grey percentage.

\footnotetext{
8 Reflectances produced by this colour in the wave length interval between $750 \mathrm{~nm}$ and $800 \mathrm{~nm}$, belong to infrared zone that can not be seen by human eye, so they do not influence the visual sensation.
} 


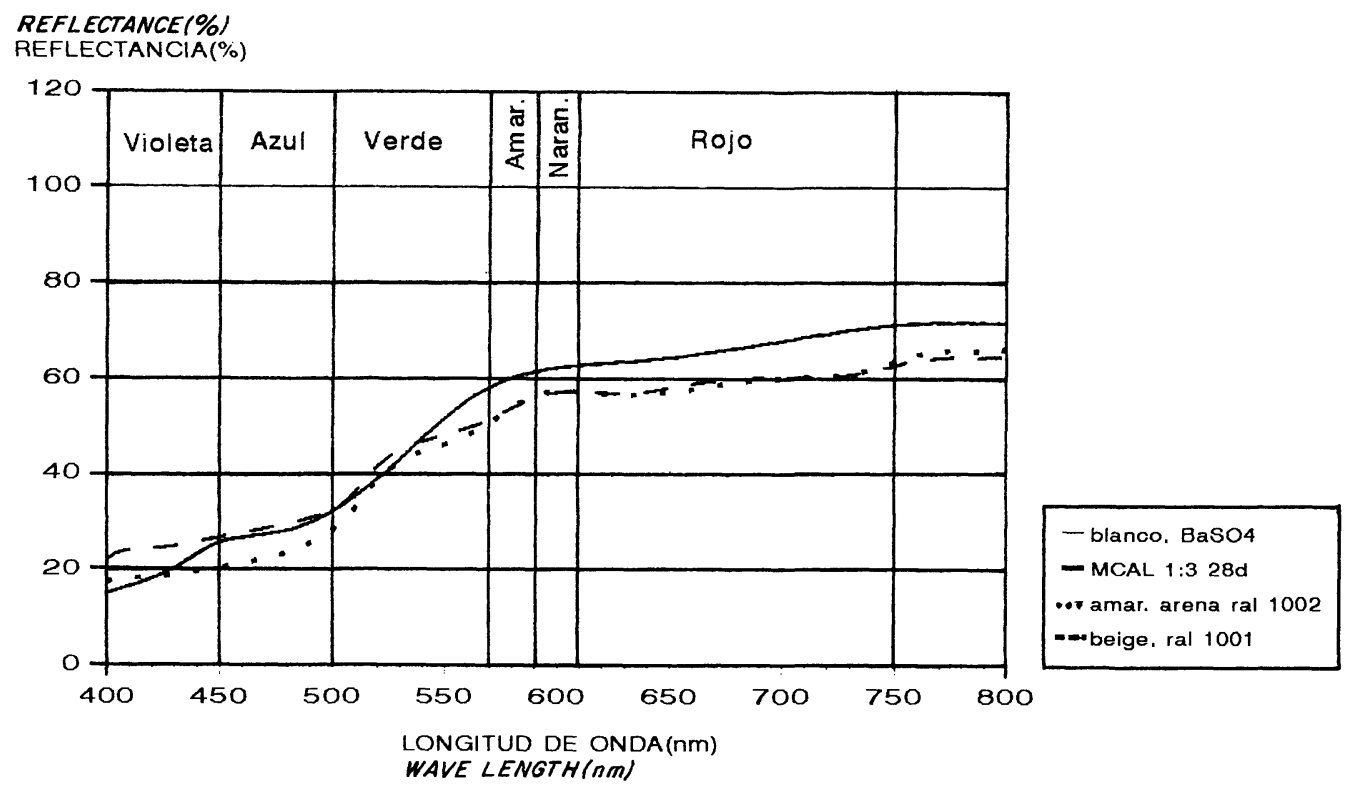

Figura 5.- Reflectancia del beige (RAL 1001), amarillo arena (RAL 1002) y MCAL.

Figure 5.- sand yellow (RAL 1002), beige (RAL 1001) and MCAL reflectance.

\section{3) Influencia de la adición de HS y del tiempo en} el color de los MCAL

\section{- Influencia de la adición de HS en el color de los MCAL}

Para este estudio se prepararon probetas de MCAL con dosificaciones del $0 \%, 5 \%$ y $10 \%$ de HS, y a los 28 días de edad, se efectuaron las medidas de la reflectancia que originaron las siguientes curvas espectrales (Figura 6).

\section{3) Silica fume addition and time influence on MCAL colour}

\section{- Silica fume addition influence on $M C A L$ colour}

For this study it were prepared MCAL test pieces with $0 \%, 5 \%$ y $10 \% \mathrm{HS}$ dosage, and at the age of 28 days, it was made reflectance measurements which generated the next spectral curves (Figure 6).

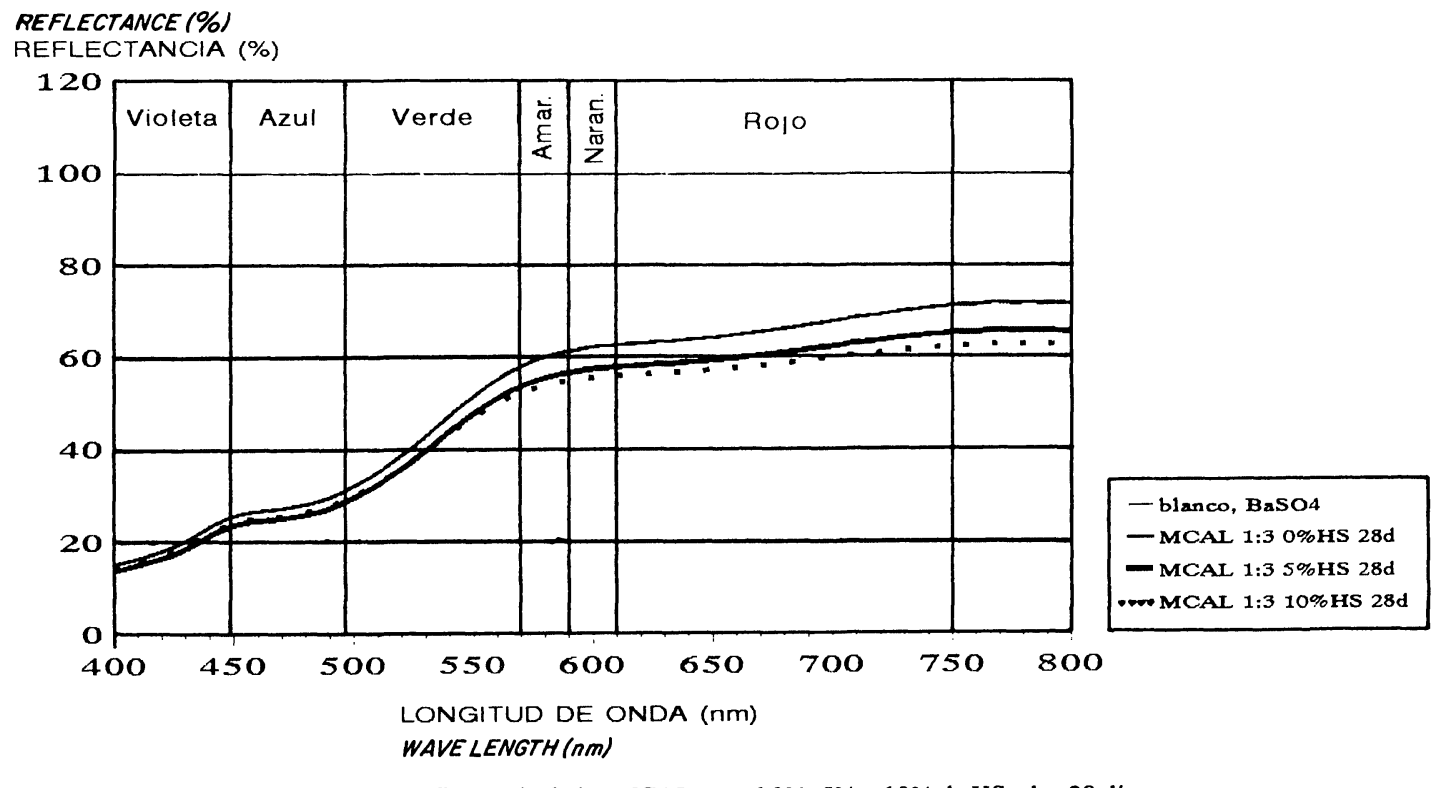

Figura 6.- Reflectancia de los MCAL con el $0 \%, 5 \%$ y $10 \%$ de HS a los 28 dias.

Figure 6.- MCAL (0\%, 5\% y 10\% HS dosage) reflectance at 28 days. 
La representación gráfica nos muestra claramente cómo se ha producido un descenso de la reflectancia en todos los tonos a medida que aumentaba el porcentaje de HS, siendo éste de mayor magnitud en los rojos, naranjas y amarillos. Los valores de $\overline{\mathrm{R}}$ han sido del $52,14 \%$, $47,97 \%$ y $46,67 \%$ para los MCAL adicionados con el $0 \%, 5 \%$ y $10 \%$ de HS respectivamente.

La interpretación del efecto producido, consiste simplemente en que el HS, que es producto de color gris (Figura 2), ha disminuido el grado de saturación del color del MCAL, dando lugar a colores más cercanos al gris del HS, que sería el color final de la serie correspondiente a la adición de porcentajes de HS cada vez más elevados.

\section{- Influencia del tiempo en el color de los MCAL}

La estabilidad del color frente al tiempo, es el último y uno de los más importantes aspectos investigados sobre el color en este trabajo. La evolución del color se ha seguido durante el período de un año, en MCAL sin dosificación de HS, y que han estado expuestos a condiciones climáticas (lluvia, radiación solar y cambios de temperatura noche-día (Tabla 2) a partir del periodo de curado de 28 días en la cámara. Las edades de medida han sido 3 meses, 6 meses y 12 meses, tal y como se puede observar en la figura 7 .

Podemos observar en la figura cómo, a medida que ha transcurrido el tiempo, se ha ido produciendo un paulatino descenso del grado de saturación del color de los MCAL, causado por la disminución de reflectancia de
The graphic shows clearly which it has been produced a reflectance decreasing in all tones in proportion to $H S$ percentage was increasing, being this of higher magnitude in reds, oranges and yellows. $\bar{R}$ values has been $52.41 \%, 47.97 \%$ and 46.67\% for MCAL mortars additioned with $0 \%, 5 \%$ y $10 \%$ of $H S$ respectively.

The interpretation of this effect, simply consist on grey HS colour (Figure 2), which has decreased the saturation degree of MCAL colour, giving colours more near from HS grey, which is the final colour of the sequence corresponding to higher addition HS percentages.

\section{- Time influence on MCAL colour}

Colour stability against time is the last and one of the most important aspects investigated about colour in this research. Colour evolution has been followed for one year in MCAL without HS dosage and exposed to environmental conditions (rain, sun radiation and night-day temperature changes (Table 2) starting from the curing period of 28 days in chamber. Measurements ages has been 3,6 and 12 months, as it can be observed in figure 7.

We can note in the upper figure that in proportion time has been happening it has produced a gradual reflectance decreasing on red, orange and yellow

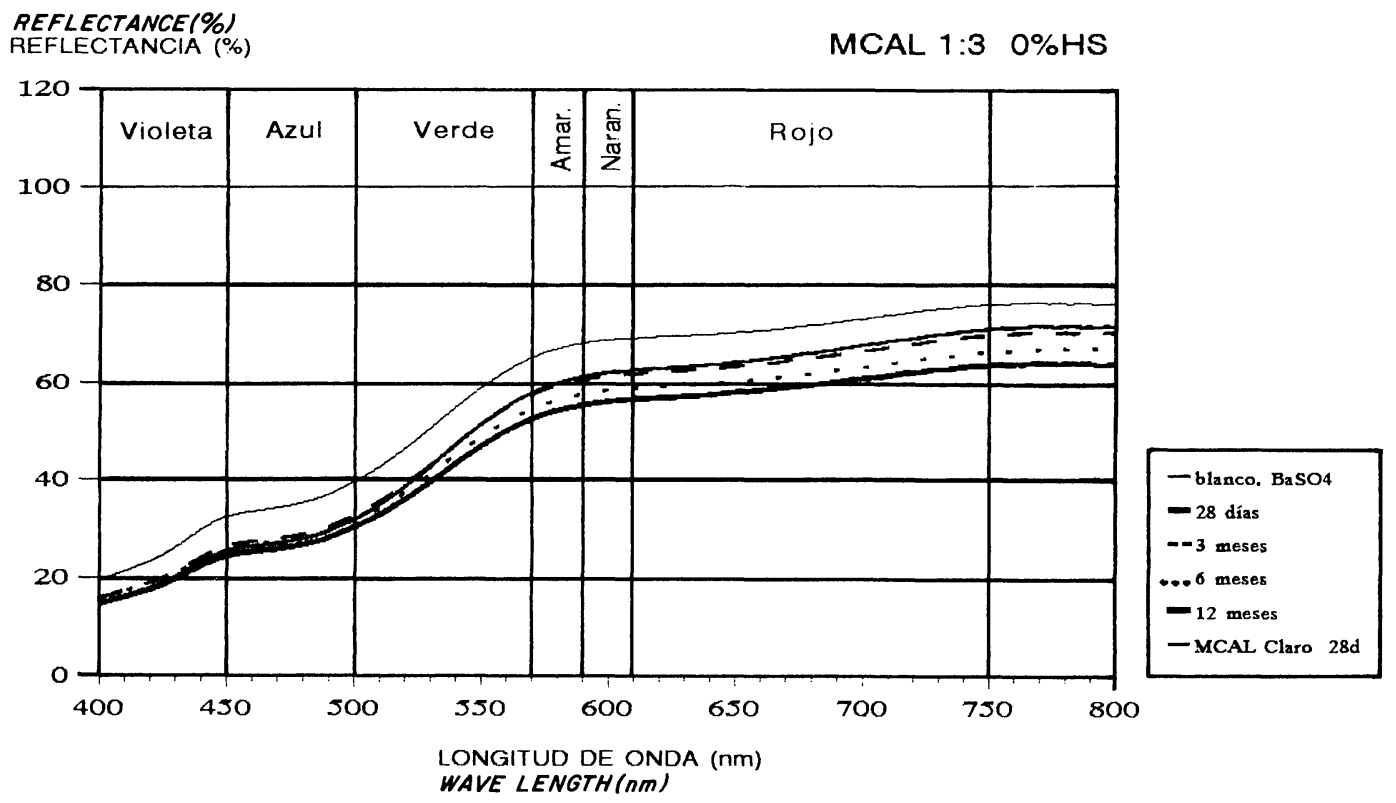

Figura 7.- Reflectancia de los MCAL a las edades de 28 días, 3,6 y 12 meses.

Figure 7.- MCAL reflectance at 28 days, 3,6 and 12 months. 
los tonos rojos, naranjas y amarillos y, en menor cuantía, de los verdes. Los valores de $\overline{\mathrm{R}}$ han sido del $52,14 \%, 51,84 \%, 49,54 \%$ y $47,47 \%$ para los MCAL a las edades de 28 días, 3, 6 y 12 meses respectivamente.

La pérdida de saturación del color del MCAL se puede atribuir a un efecto externo de asentamiento y absorción de polvo atmosférico, de colores poco saturados, sobre la superficie porosa de la probeta, que, a pesar de la limpieza de la misma con anterioridad a la realización de la medida, no lo debe eliminar en su totalidad. Para apoyar esta hipótesis nos basamos en la gran estabilidad de la goethita frente a las condiciones ambientales de temperatura y humedad, siendo este óxido de hierro no alterable a temperaturas inferiores a los $200^{\circ} \mathrm{C}$ y en medios neutros o básicos (6).

\section{CONCLUSIONES}

La metodología de medida y evaluación del color basada en la espectrofotometría UV-VIS, se ha presentado como una técnica de fácil aplicación e interpretación, con validez a la hora de establecer con objetividad comparaciones relativas a la variación de los atributos de tonalidad, claridad y saturación del color que han sufrido las muestras de mortero de cal y albero, por efecto de la adición de HS y de la exposición ambiental en el período de un año.

Se ha de comentar, a modo de juicio crítico, que su aplicación en otro tipo de morteros o materiales de construcción con colores menos homogéneos, probablemente conduzca a la introducción de otras técnicas de preparación de muestras o a tratamientos estadísticos de las diferentes curvas espectrales obtenidas para un mismo material. Asímismo, queda por abordar el estudio de la influencia de la textura del material (lisa, rugosa, con poros, etc.) en las medidas realizadas por medio de esta técnica. tones, and also on greens but in less extent. $\bar{R}$ values has been 52.14\%, 51.84\%, 49.54\% and $47.47 \%$ for MCAL aged 28 days, 3, 6 and 12 months respectively.

Saturation loss on MCAL colour can be attributed to an external effect of atmospherical dust absorption, with few saturated colours, over the porous surface of the mortar test piece, which despite of its cleaning before making the measurement, it must not eliminate it completely. Supporting this hypothesis it is the real fact of the great stability of gohetite against temperature and humidity environmental conditions, being this iron oxide stable at lower temperatures than $200{ }^{\circ} \mathrm{C}$ and at neutral and alkaline environment (6).

\section{CONCLUSIONS}

Colour measurement and evaluation methodology based in UV-VIS spectrophotometry, it has resulted in an easy application and interpretation technique, valid when it is necessary to establish objectively comparisons related to tone, brightness and saturation attributes variation which MCAL samples have suffered by $H S$ addition and environmental exposure for one year.

It is necessary to comment as a critical opinion, that its application to other mortars or building materials with less homogeneous colours, probably leads up to introduce another techniques for preparing samples or statistics treatments of the different spectral curves obtained for the same material. Also it is pending to broach the study of texture influence (even, rough, porous, etc.) in measurements made by this technique.

\section{BIBLIOGRAFÍA}

(1) GÁRATE RojAS, I.: "Artes de la cal". Ministerio de Cultura, Dirección General de Bellas Artes y Archivos. Instituto de Conservación y Restauración de Bienes Culturales. Madrid, 1993, 297 pp.

(2) OLSEN, EUGENE D.: "Métodos ópticos de análisis". Editorial Reverté S.A., 1986.

(3) ALEJANDRE SÁNCHEZ, F.J.: "El albero como árido para la fabricación de morteros de color". Tesis Doctoral, 1997. Universidad de Sevilla., $255 \mathrm{pp}$.

(4) AENOR. NORMA UNE 83-821 experimental.: Morteros. Métodos de ensayo. Morteros endurecidos. Determinación de las resistencias a flexión y a compresión, 1992.

(5) JACKSON, M.L.: "Soil Chemical Analysis-Advanced Course". 2nd Ed. Published by the author, Madison, 1969, Wis., 895 pp.

(6) SCHWERTMANN, U.; TAYLOR, R.M.: "Minerals in Soils Environments". SSSA Book series, no. 1. Soil Science Society of America. Madison, USA, 1989. 